\title{
Preparation of polyaniline based nanocomposite material and their environmental applications
}

\author{
R. Bushra • M. Shahadat • M. A. Khan • \\ R. Adnan · M. Arshad • M. Rafatullah • \\ Mu. Naushad
}

Received: 14 June 2014/Revised: 28 October 2014/Accepted: 22 November 2014/Published online: 3 December 2014

(C) Islamic Azad University (IAU) 2014

\begin{abstract}
This present paper reports the synthesis and environmental applications of conducting polyanilineSn(IV)tungstomolybdate nanocomposite. The material was synthesized via a very simple chemical route and characterized by using various instrumental techniques. Physicochemical properties, $\mathrm{pH}$ titrations, and elution behavior were studied to exploit the ion-exchange capability of nanocomposite. Electrical conducting studies were performed by using 4-in-line-probe (Direct Current) electrical conductivity measuring instrument. The conductivity of the material was found to be in the range of semiconductor's. Distribution coefficient values were measured in demineralized water and varying
\end{abstract}

Electronic supplementary material The online version of this article (doi:10.1007/s13762-014-0726-5) contains supplementary material, which is available to authorized users.

R. Bushra $(\bowtie) \cdot$ R. Adnan

School of Chemical Sciences, Universiti Sains Malaysia, 11800

Pulau Penang, Malaysia

e-mail: bushra.chem07@gmail.com

M. Shahadat · M. A. Khan

Analytical Research Laboratory, Department of Chemistry,

Aligarh Muslim University, Aligarh 202002, India

\section{Arshad}

Medicinal Chemical Research Laboratory, Centre for Interdisciplinary Research in Basic Sciences, Jamia Millia Islamia, New Delhi 110025, India

M. Rafatullah

School of Industrial Technology, Universiti Sains Malaysia, 11800 Pulau Penang, Malaysia

$\mathrm{Mu}$. Naushad

Department of Chemistry, College of Science, Bld\#5, King Saud University, Riyadh, KSA concentration of dimethyl sulfoxide, and on the basis of partition coefficient values, the material was found to be selective for $\mathrm{Pb}^{2+}$ ions. This nanocomposite material has been fruitfully applied for the treatment of heavy metals from synthetic mixture and industrial waste water samples. The limit of detection and the limit of quantification for $\mathrm{Pb}^{2+}$ ion were found to be 0.97 and $3.24 \mu \mathrm{g} \mathrm{L}^{-1}$, respectively. The material was also tested for antimicrobial activity, and it was found that besides its use as an ion-exchange material, polyaniline-Sn(IV)tungstomolybdate is successfully used as an antimicrobial agent and as well as semiconductor.

Keywords Antimicrobial - Fabrication - Hybrid - Metal ions · Remediation · Wastewater

\section{Introduction}

Aquatic environment is badly affecting by the tremendous use of heavy metals over the past few decades, which results in an increased influx of metallic substances in water (Yang and Rose 2003). Heavy metal ions are considered as an important class of human carcinogens. Among various metal ions, arsenic, cadmium, chromium VI, beryllium, and nickel are accepted as human carcinogens in one or another form or in particular routes of exposure (NTP 2002). The mechanism(s) responsible for metal carcinogenesis is elusive, partly owing to the complex nature of metal interactions with biological systems. A number of metals including carcinogenic metals follow the metabolic pathway similar to the essential metals. This is probably because of similar binding preferences between carcinogenic metals and nutritionally essential metals (Clarkson 1986). Thus, 
contamination of fresh water with a wide range of pollutants has become a matter of great concern, not only to public water supplies, but also to aquatic life. Rivers also have been excessively contaminated with heavy metals that are usually released from domestic, industrial, mining, and agricultural effluents (Vander Oost et al. 2003). Populations are increasingly demanding a cleaner environment in general and reductions in the amounts of contaminants. So, in developed countries, there has been the imposition of new and more restrictive regulations to make the environment free of contaminants (European Commission, Regulation 2006; Figueroa 2008). A number of methods have been exploited for the treatment of these toxic metal ions (Hojati and Landi 2014; Kurniawan et al. 2006; Lin 2014; Poyraz and Taspinar 2014; Singh and Singh 2012). However, the adsorption by ion-exchange resins has gained popularity for being more selective as compared to other methods (Akieh et al. 2008; Bag et al. 2007).

Pure organic and inorganic ion-exchange resins have been found to be useful for the removal of toxic heavy metals (Gupta et al. 2014) from water bodies. It was found that the inorganic materials have several superior qualities for the treatment of waste streams compared with organic resins, due to their high thermal stability and good compatibility. However, the slow mass-transfer rate in column operation has been the impeding factor for extensive applications (Saberi et al. 2010) of inorganic ion exchangers. Hence, in order to prevail over these drawbacks, composite ion exchangers (Shahadat et al. 2014; Inamuddin 2010; Khan et al. 2014) were synthesized by introducing inorganic materials into the matrix of organic polymer polyaniline (PANI). These composite materials have been widely studied and showed improved qualities with respect to those of pure inorganic and organic counterparts, in terms of better selectivity, good mechanical and chemical resistance, more regular granular form, lower solubility in water, and better exchange of kinetics (Vatutsina et al. 2007; Hafez et al. 2001).

Owing to the above mentioned advantages, composite materials have applications in various fields (Nabi et al. 2009, 2010, 2011a; Bushra et al. 2012, 2014; Mohamed Jaffer Sadiq and Samson Nesaraj 2014), which are of economical and environmentally importance. The present paper reports synthesis, characterization, and environmental applications of polyaniline-Sn(IV)tungstomolybdate nanocomposite cation-exchange material.

It is a collaborative work of Aligarh Muslim University [Aligarh (UP), India] and University Sains Malaysia [USM, Pulau Penag(Malaysia)]. Practical work is carried out in Aligarh Muslim University (winter 2014) supported by financial assistance through USM RU grant.

\section{Materials and methods}

Materials

The reagents which are utilized for the synthesis of composite material include solutions of stannic chloride pentahydrate $(0.10 \mathrm{M})$, sodium molybdate $(0.10 \mathrm{M})$, and sodium tungstate $(0.10 \mathrm{M})$ which are all prepared in demineralized water. Potassium persulfate $(0.1 \mathrm{M})$ and $10 \%$ stock solution $(\mathrm{v} / \mathrm{v})$ of aniline were prepared in $1 \mathrm{M} \mathrm{HCl}$. All are acquired from E-Merck and CDH (India).

\section{Apparatus}

For all spectrophotometric studies conducted in this work, UV-3200 double beam spectrophotometer was used which was purchased from LabIndia. All IR spectra (infra red) were recorded on spectrometer Perkin Elmer (Model number 1730 , USA) using $\mathrm{KBr}$ disk method. For X-ray diffraction (XRD) measurement, X'Pert PRO analytical diffractometer (Model number PW-3040/60) from Netherlands with $\mathrm{CuK} \alpha$ radiation using scanning electron microscopy instrument (SEM; LEO, $435 \mathrm{VF}$ ) was employed. TEM analysis was carried out on a Jeol H-7500. Detection of toxic metals in environmental samples were determined by utilizing flame atomic absorption spectrometer with a model GBC-932-plus (GBC Scientific, Australia).

\section{Polyaniline synthesis}

Polyaniline which is one of the most studied conducting polymers is synthesized by using oxidative polymerization method. In this method, monomer of aniline $(10 \%)$ was polymerized by the addition of an oxidizing agent potassium persulfate in varying ratio under constant stirring below $4{ }^{\circ} \mathrm{C}$ for $1 \mathrm{~h}$ (Nabi et al. 2011b), a dark colored green gel of polyaniline was obtained.

\section{Synthesis of PSTM}

An inorganic precipitate of $\mathrm{Sn}(\mathrm{IV})$ tungstomolybdate was prepared by adding the solutions of sodium tungstate and sodium molybdate $(0.1 \mathrm{M})$ to $0.1 \mathrm{M}$ solution of stannic(IV) chloride with varying volume ratios under continuous stirring for $1 \mathrm{~h}$. The $\mathrm{pH}$ of the mixture was maintained by adding nitric acid or ammonia solution. White gel type slurry was obtained. Then, polyaniline gel was added to the white precipitate of $\mathrm{Sn}$ (IV)tungstomolybdate with continuous stirring and kept it for $24 \mathrm{~h}$ for digestion and then it is filtered, washed (to remove excess acid) and dried in an 
oven at $50 \pm 2{ }^{\circ} \mathrm{C}$. Afterward, it is converted into $\mathrm{H}^{+}$form by treating it with $1 \mathrm{M}$ nitric acid. Then, it is again washed with demineralized water and dried at $50 \pm 2{ }^{\circ} \mathrm{C}$. Thus, a number of samples of composite material PSTM were prepared under varying experimental conditions (Table S1).

Ion-exchange capacity

Adsorption capability of the composite material was measured by calculating ion-exchange capacity. For determining the ion-exchange capacity, composite material was packed in a glass column of $0.5 \mathrm{~cm}$ internal diameter. For releasing of $\mathrm{H}^{+}$ions from the material, different metal nitrate solutions were passed through it at the flow rate of $1.0 \mathrm{~mL} \mathrm{~min}{ }^{-1} . \mathrm{H}^{+}$ions in the effluent were then determined by titrating it against the standard solution of $0.1 \mathrm{M}$ sodium hydroxide.

$\mathrm{pH}$ titration

The nature of available functional group (mono-, bi-, and tri-functionals) in the composite material was examined by metal ions by using batch method. In this method, $300 \mathrm{mg}$ of composite material $\left(\mathrm{H}^{+}\right.$form) with $30 \mathrm{~mL}$ of different metal nitrate solution was placed in various conical flasks of $50 \mathrm{~mL}$. Then, it was shaken for a particular time of $6 \mathrm{~h}$ in a temperature-controlled shaker at $25 \pm 2{ }^{\circ} \mathrm{C}$ to attain equilibrium. The metal ion concentration before and after the equilibrium was determined by titrating against a standard solution of EDTA $(0.01 \mathrm{M})$. The distribution coefficient values were calculated by using the equation:

$K_{d}=\frac{\text { milli equivalent of metal ions } / \mathrm{g} \text { of ion }- \text { exchanger }}{\text { milli equivalent of metal ions } / \mathrm{mL} \text { of solution }} \mathrm{mL} \mathrm{g}^{-1}$

$K_{d}=\frac{(I-F) / 300 \mathrm{mg}}{F / 30 \mathrm{~mL}}$

where $I$ is the initial amount of metal ion in solution phase without treatment with exchanger.

$F$ is the final amount of metal ion in solution phase after treatment with exchanger.

The sorption of metal ions involves the exchange of the $\mathrm{H}^{+}$ions in exchanger phase with that of metal ions in solution phase.

For example:

$\begin{array}{cccc}2 \mathrm{R}-\mathrm{H}^{+} & \mathrm{M}^{2+} & \begin{array}{c}\mathrm{R}_{2}-\mathrm{M} \\ \text { Exchanger phase }\end{array} \\ \text { Solution phase } & \text { Exchanger phase } & 2 \mathrm{H}^{+} \\ \text {where, } \mathrm{R}=\text { =PSTM } & & & \end{array}$

performing $\mathrm{pH}$ titrations studies using Topp and Pepper method (Topp and Pepper 1949). In this method, $1.0 \mathrm{~g}$ composite material (in $\mathrm{H}^{+}$form) was placed into several conical flasks $(50 \mathrm{~mL})$ followed by the addition of equimolar solutions of alkali metal chlorides and their corresponding hydroxides. The ionic strength of each sample was maintained by adjusting the volume to $50 \mathrm{~mL}$.

\section{Elution behavior}

This study was performed for the elution of $\mathrm{H}^{+}$ions from the column containing $1.0 \mathrm{~g}$ exchanger using $1.0 \mathrm{M}$ $\mathrm{NaNO}_{3}(250 \mathrm{ml})$ solution. Each $10.0 \mathrm{~mL}$ fraction of collected effluent was titrated against a standard $\mathrm{NaOH}$ solution.

\section{Sorption behavior}

Distribution coefficients with cation exchanger PSTM in different solvent systems have been determined for several
Selective separation of metal ion from synthetic mixtures

Selective separations of some selective metal ions $(0.1 \mathrm{M})$ $\left(\mathrm{Pb}^{2+}\right.$ and $\left.\mathrm{Hg}^{2+}\right)$ from the synthetic mixtures containing $\left(\mathrm{Pb}^{2+}, \mathrm{Cu}^{2+}, \mathrm{Cd}^{2+}, \mathrm{Mg}^{2+}, \mathrm{Zn}^{2+}\right)$ and $\left(\mathrm{Cu}^{2+}, \mathrm{Hg}^{2+}, \mathrm{Ni}^{2+}\right.$, $\left.\mathrm{Zn}^{2+}, \mathrm{Mg}^{2+}, \mathrm{Er}^{3+}, \mathrm{Ce}^{3+}\right)$ were achieved on columns of composite material by employing the elution technique. In this technique, composite material was packed in a glass column of $1.0 \mathrm{~cm}$ internal diameter that is washed with demineralized water. After that, mixture of metal ions was poured onto a column with a flow rate $\left(0.3-0.5 \mathrm{~mL} \mathrm{~min}^{-1}\right)$ until a small amount remained above the surface of the material. Later on, it was rinsed with demineralized water. Metal ions were then eluted with appropriate mobile phase, and the collected effluent in $10 \mathrm{~mL}$ fractions was titrated against the standard solution of di-sodium salt of $\operatorname{EDTA}(0.01 \mathrm{M})$. The amount of $\mathrm{Pb}^{2+}$ and $\mathrm{Hg}^{2+}$ ions in the synthetic mixture was varied, while the amount of other metal ions is kept constant (Table 1 and Table S3). 
Table 1 Selective separations of $\mathrm{Pb}^{2+}$ ion from a synthetic mixture of $\mathrm{Pb}^{2+}, \mathrm{Cu}^{2+}, \mathrm{Cd}^{2+}, \mathrm{Mg}^{2+}$, and $\mathrm{Zn}^{2+}$ ions on PANI-stannic(IV)tungstomolybdate cation exchanger columns

\begin{tabular}{lllllc}
\hline $\begin{array}{l}\text { S. } \\
\text { no. }\end{array}$ & $\begin{array}{l}\text { Amount of } \\
\mathrm{Pb}^{2+} \text { loaded } \\
(\mathrm{mg})\end{array}$ & $\begin{array}{l}\text { Amount of } \\
\mathrm{Pb}^{2+} \text { found } \\
(\mathrm{mg})\end{array}$ & $\begin{array}{l}\% \\
\text { Recovery }\end{array}$ & $\begin{array}{l}\text { Eluent } \\
\text { used }\end{array}$ & $\begin{array}{l}\text { Eluent } \\
\text { volume } \\
(\mathrm{mL})\end{array}$ \\
\hline 1 & 4.14 & 4.06 & 98 & $\mathrm{a}$ & 90 \\
2 & 8.28 & 8.03 & 97 & $\mathrm{a}$ & 100 \\
3 & 12.43 & 12.31 & 99 & $\mathrm{a}$ & 100 \\
\hline
\end{tabular}

${ }^{\text {a }}$ Average of five replicates determinations, $a=0.1 \mathrm{M} \mathrm{DMSO}$

Table 2 Analysis of $\mathrm{Ni}^{2+}, \mathrm{Pb}^{2+}$, and $\mathrm{Fe}^{3+}$ ions in different industrial samples on the columns of PANI-stannic(IV)tungstomolybdate cation exchanger

\begin{tabular}{|c|c|c|c|c|}
\hline Samples & Method & $\begin{array}{l}\text { Amount of } \\
\mathrm{Ni}^{2+} \text { ion } \\
\text { found }^{\mathrm{a}}(\mu \mathrm{g} \\
\left.\mathrm{L}^{-1}\right) \\
(\% \mathrm{RSD})^{\mathrm{b}}\end{array}$ & $\begin{array}{l}\text { Amount of } \\
\mathrm{Pb}^{2+} \text { ion } \\
\text { found }^{\mathrm{a}}(\mu \mathrm{g} \\
\left.\mathrm{L}^{-1}\right) \\
(\% \mathrm{RSD})^{\mathrm{b}}\end{array}$ & $\begin{array}{l}\text { Amount of } \\
\mathrm{Fe}^{3+} \text { ion } \\
\text { found }^{\mathrm{a}}(\mu \mathrm{g} \\
\left.\mathrm{L}^{-1}\right) \\
(\% \mathrm{RSD})^{\mathrm{b}}\end{array}$ \\
\hline \multirow[t]{2}{*}{ B-1 } & Direct $^{c}$ & 2.2. (2.8) & $8.1(2.6)$ & 3.7 (2.9) \\
\hline & $\mathrm{SA}^{\mathrm{d}}$ & $3.3(2.1)$ & $8.9(2.0)$ & $4.0(2.2)$ \\
\hline \multirow[t]{2}{*}{ B-2 } & Direct & $3.1(2.2)$ & $9.8(3.8)$ & $2.2(1.5)$ \\
\hline & SA & $3.9(3.8)$ & $10.0(3.0)$ & $3.0(1.0)$ \\
\hline \multirow[t]{2}{*}{ B-3 } & Direct & $9.7(1.1)$ & $9.8(3.8)$ & $2.2(2.5)$ \\
\hline & SA & $9.5(1.0)$ & $8.9(2.2)$ & $2.0(2.0)$ \\
\hline
\end{tabular}

B-1 (Talanagri, Aligarh), B-2 (Ramghat road, Aligarh), B-3 (Upperfort, lock and key Industry, Aligarh)

${ }^{a}$ Average of three replicate determinations

b \% RSD, Relative standard deviation, '-' indicates not detected

c Recommended procedure applied without spiking

${ }^{\mathrm{d}}$ Recommended procedure after spiking (standard addition method)

Evaluation of heavy metal ions $\left(\mathrm{Pb}^{2+}, \mathrm{Ni}^{2+}\right.$, and $\left.\mathrm{Fe}^{3+}\right)$ in different industrial effluents by using column of PSTM followed by FAAS

A number of waste water samples were collected from different industrial areas of Aligarh City (UP, India). All samples were filtered through Millipore cellulose membrane filter $(0.45 \mu \mathrm{m}$ pore size $)$ and acidified to $\mathrm{pH} 2$ with concentrated $\mathrm{HNO}_{3}$. The waste water samples were then subjected to the recommended procedure (column operation) for preconcentration. Finally, the concentrations of metal ions were determined by FAAS, and results are summarized in Table 2.

\section{Recommended procedure}

For the preconcentration procedure, $\mathrm{pH}$ of the solution $(500-1000 \mathrm{~mL})$ was adjusted to $\sim 6.0$ with hydrochloric acid and passed through the exchanger column at a flow rate of $5 \mathrm{~mL} \mathrm{~min}{ }^{-1}$. The adsorbed ions were then eluted with $5 \mathrm{~mL}$ of $2 \mathrm{M}$ nitric acid in acetone with a flow rate of $1 \mathrm{~mL} \mathrm{~min}{ }^{-1}$. The metal ion content of the eluent was measured by flame atomic absorption spectrometer.

Antimicrobial activity and minimal inhibitory concentrations (MIC) of composite material PSTM

Organism culture and in vitro screening for antibacterial activity were done by using disk diffusion method with minor modifications. Staphyllococcus aureus, Staphyllococcus epidermidis, Proteus mirabilis, and Escherichia coli were sub-cultured in nutrient agar medium and incubated for $18 \mathrm{~h}$ at $37^{\circ} \mathrm{C}$. The bacterial cells were suspended for incubation according to the McFarland protocol in saline solution to produce a suspension of about $10^{5} \mathrm{CFU} / \mathrm{mL}$ (colony forming unit per $\mathrm{mL}$ ). A fix volume of this suspension $(10 \mathrm{~mL})$ was mixed with $10 \mathrm{~mL}$ of sterile antibiotic agar at $40{ }^{\circ} \mathrm{C}$ and poured onto an agar plate in a laminar flow cabinet. Five paper disks $(6.0 \mathrm{~mm}$ diameter $)$ were fixed onto nutrient agar plate. One milligram of each test compound was dissolved in $100 \mathrm{~mL}$ DMSO to prepare stock solution. From the stock solution, different dilutions of each test compound were prepared and poured over disk plate. Ciprofloxacin was used as a standard drug (positive control) and DMSO was used as the negative control. The susceptibility of the bacteria to the test compounds was determined by the formation of an inhibitory zone after $18 \mathrm{~h}$ of incubation at $37{ }^{\circ} \mathrm{C}$. The results were compared with the positive control, and the zone of inhibitions was measured at the MIC. MICs were determined by macrodilution technique. The nutrient broth, which contained logarithmic serially twofold diluted amount of test compounds and controls was inoculated within approximately $10^{5} \mathrm{CFU} \mathrm{mL} \mathrm{mL}^{-1}$ of actively dividing bacteria cells. The cultures were incubated for $18 \mathrm{~h}$ at $37^{\circ} \mathrm{C}$, and the growth was monitored visually and spectrophotometrically.

\section{Conductivity measurements}

Conducting studies on composite material was performed by treating the sample with $0.1 \mathrm{M}$ solution of $\mathrm{HCl}$ (as a doping agent). After that sample was washed repeatedly with demineralized water in order to remove excess acid, and finally, it was dried at $50{ }^{\circ} \mathrm{C} .300 \mathrm{mg}$ of this dried material was grounded, and pellets were made at a pressure of $25 \mathrm{kN}$ for conductivity measurements. The thickness of the pellet was measured by a micrometer. Thus, the electrical conductivity measurements for doped $(0.1 \mathrm{M} \mathrm{HCl}$ solution) and undoped samples of nanocomposite material were examined at different temperatures (between 30 to $200{ }^{\circ} \mathrm{C}$ ).

Electrical conductivity of the samples was determined by using the following equation: 


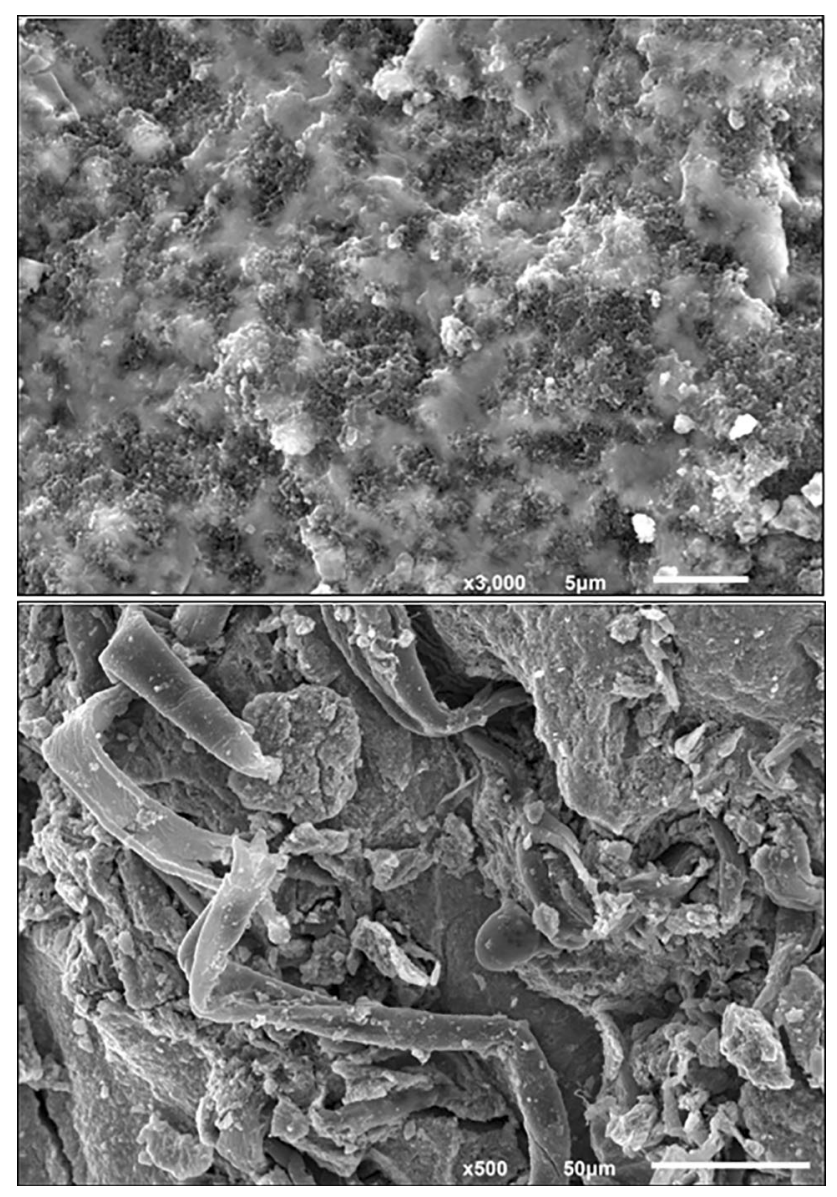

Fig. 1 SEM images of PANI-Sn(IV)tungstomolybdate cationexchange material at different magnifications

$$
\begin{aligned}
& \sigma=\sigma_{0} / G_{7}(W / S) \\
& G_{7}(W / S)=\ln 2(2 S / W) \\
& \sigma_{0}=2 \pi S(V / I)
\end{aligned}
$$

where $\sigma$ is the electrical conductivity in $\mathrm{S} \mathrm{cm}^{-1}, \mathrm{G}_{7}(\mathrm{~W} / \mathrm{S})$ is the correction factor that was used for the non-conducting bottom surface and is a function of thickness of the sample under investigation $(\mathrm{cm})$ and $\mathrm{S}$ is the probe spacing $(\mathrm{cm}), \mathrm{I}$ is the current $(\mathrm{A})$, and $\mathrm{V}$ is the voltage. Isothermal stability of doped composite $(1 \mathrm{M} \mathrm{HCl})$ was measured in terms of DC electrical conductivity retention at different temperatures.

\section{Results and discussion}

Different samples of PSTM were prepared by varying the experimental conditions such as $\mathrm{pH}$ and mixing volume ratio. On increasing the $\mathrm{pH}$, ion uptake capacity of the material was decreased due to metal hydroxide formation. Varying the mixing volume ratios of the reactants also affects the ion-exchange capacity of the composite material
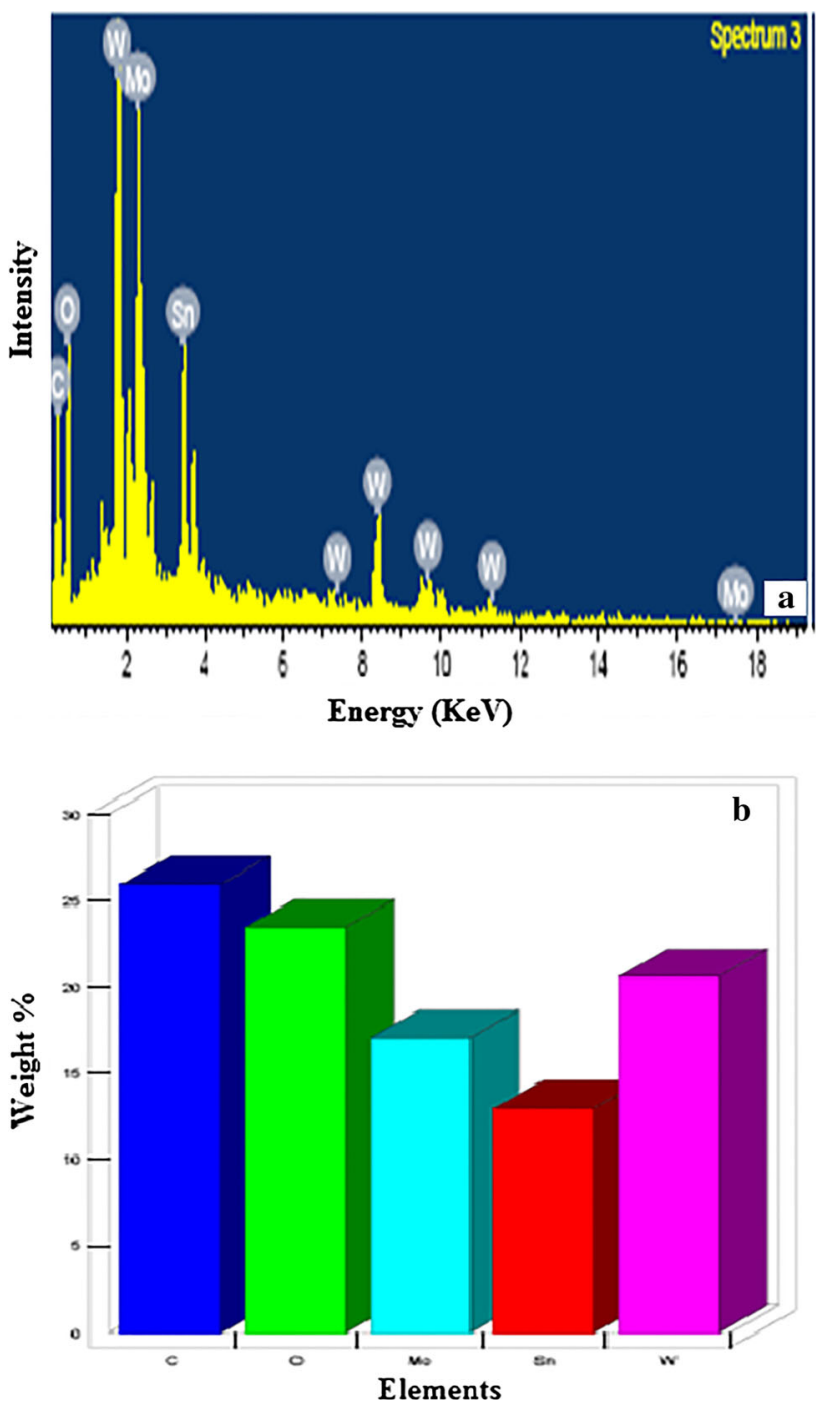

Fig. 2 EDAX spectrum of (a) PANI-Sn(IV)tungstomolybdate cationexchange material and its (b) percentage content

(Table S1). On the basis of good ion-exchange capacity and better yield, sample M-8 is selected for detailed studies. Elution behavior study was performed to estimate the minimum amount of solvent needed to release $\mathrm{H}^{+}$from the exchanger. The experiment indicated that only $120 \mathrm{~mL}$ $\mathrm{NaNO}_{3}$ solution $(1.0 \mathrm{M})$ was required to release total $\mathrm{H}^{+}$ ions from $1.0 \mathrm{~g}$ of PSTM (Fig. S1). The nature of the ionogenic group present in the composite material was determined by $\mathrm{pH}$ titration studies on some metal halides and their corresponding hydroxides (Fig S2). This study clearly shows the bifunctional behavior of the composite material.

The surface morphology of PSTM was examined by SEM analysis (Fig. 1). SEM images depict irregular morphology with a large number of porous cavities. Because of porous nature, the material can easily adsorb metal ion, as a result of enhancing ion-exchange capacity. EDAX spectrum (Fig. 2a, b) shows that the overall amount of $\mathrm{C}, \mathrm{O}$, 


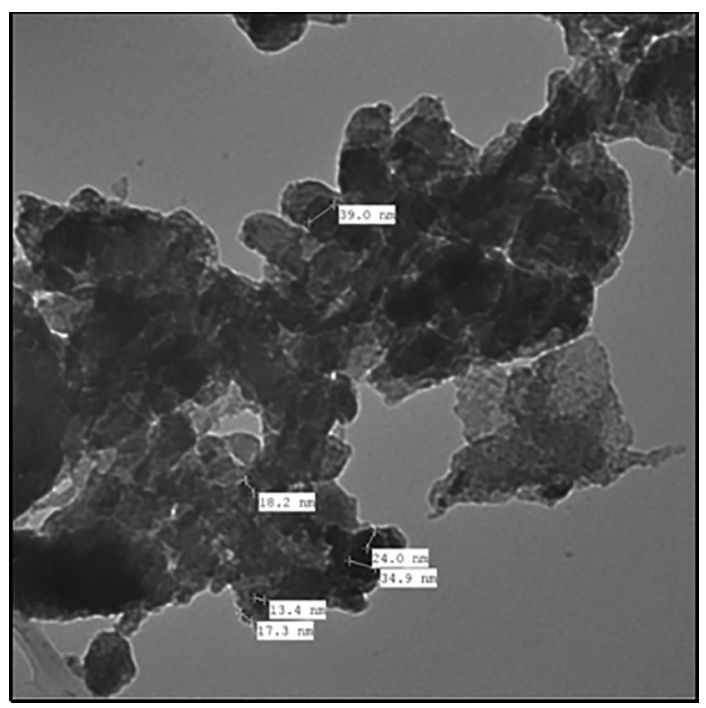

Fig. 3 TEM image of PANI-Sn(IV) tungstomolybdate cationexchange material

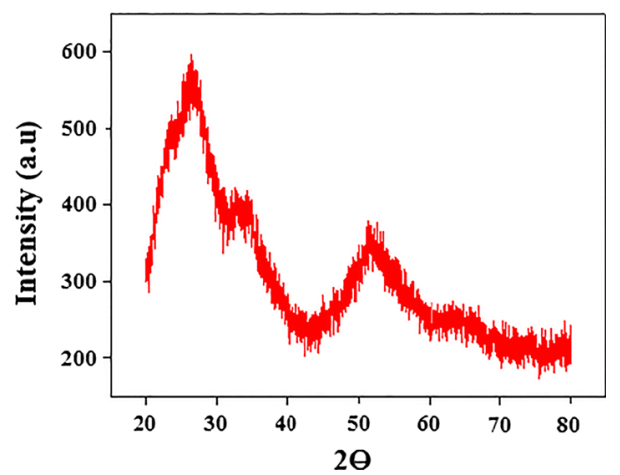

Fig. 4 X-ray diffraction pattern of PANI-Sn(IV)tungstomolybdate

Mo, Sn, and W in the composite material was found to be $25.96,23.44,17.04,12.97$, and 20.59 wt $\%$, respectively. TEM studies revealed that the composite material shows particle size in the range of 17-39 $\mathrm{nm}$. Thus, it can be considered as nanocomposite material (Fig. 3). The amorphous nature of the material was confirmed by X-ray analysis (Fig. 4).

\section{Measurement of electrical conductivity}

By using 4-in-line-probe DC electrical conductivity measuring instrument, electrical conductivity of doped and undoped samples of nanocomposite material was measured. It was found that the conductivity of material increases with the increase in temperature which implies the characteristic behavior semiconductor. $\mathrm{HCl}$-doped nanocomposite demonstrates higher conductivity than the undoped material which may be attributed due to the charge-transfer reaction between the chains of PSTM and

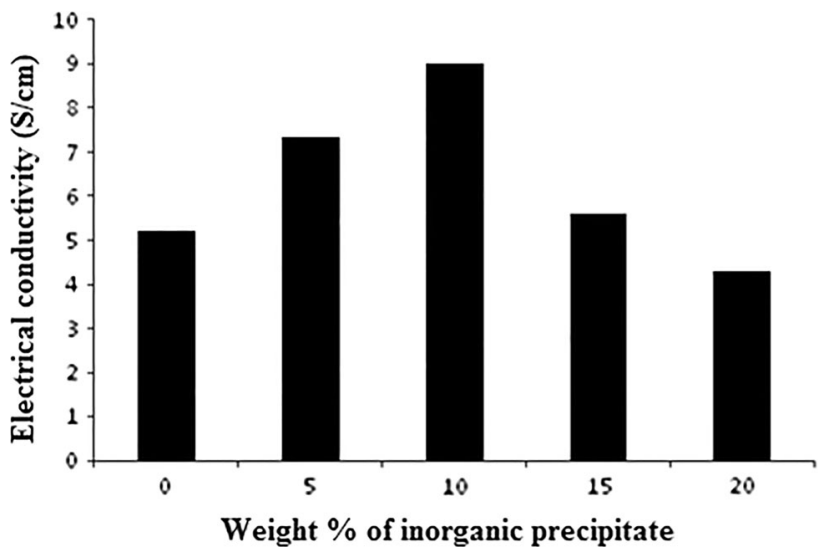

Fig. 5 Electrical conductivity versus the varying percentage of inorganic precipitate in nanocomposite

the doping agent, $\mathrm{HCl}$ (Fig S3). It was observed that the temperature dependence of the plot of log conductivity versus 1000/T (K-1) (Fig S4) followed the Arrhenius equation. Therefore, nanocomposite material follows the Arrhenius model. The energies of activation of $\mathrm{HCl}$ treated and as-prepared samples were found to be as 1.7 and $1.59 \mathrm{eV}$, respectively. Figure 5 shows the variation of electrical conductivity of composite material by varying percentage of inorganic precipitate. The results show that maximum increase in conductivity occurred at $10 \mathrm{wt} \%$, after which the conductivity started to decrease. It is believed that further increase in the percentage of inorganic precipitate hinders the carrier transport between conjugated chains of PANI (Su and Kuramoto 2000; Xu et al. 2005) that leads to decrease in the overall conductivity.

Thermal stability of composite material in terms of DC electrical conductivity retention was studied under isothermal conditions at the $10 \mathrm{~min}$ time interval at different temperatures $\left(50,90\right.$ and $\left.130{ }^{\circ} \mathrm{C}\right)$. Figure S5 represents the measurement of electrical conductivity with respect to time. Electrical conductivity was quite stable at 50 and $90{ }^{\circ} \mathrm{C}$, which demonstrates that composite material followed Arrhenius equation for the temperature dependence of the electrical conductivity under ambient temperature conditions. Decrease in conductivity at $130{ }^{\circ} \mathrm{C}$ is due to the loss of dopant and degradation of composite material.

\section{Environmental applications}

Distribution coefficient values were measured in various solvent systems, as it is evident from Table $\mathrm{S} 2$ that sorption of the metal ion increases with decrease in the concentration of the acid. Among all metal ions, $\mathrm{Pb}^{2+}$ ion was highly sorbed by the composite material and the results show that the composite material is selective toward $\mathrm{Pb}^{2+}$ ion. The 
Table 3 Inhibitory effects of composite material PANI-stannic(IV)tungstomolybdate on microorganisms

\begin{tabular}{|c|c|c|c|c|}
\hline \multirow[t]{3}{*}{ Compounds } & \multicolumn{4}{|c|}{ Zone of inhibition (mm) } \\
\hline & \multicolumn{2}{|l|}{ Gram positive } & \multicolumn{2}{|l|}{ Gram negative } \\
\hline & S. aureus & S. epidermidis & P. mirabilis & E. coli \\
\hline Composite material & $21.58 \pm 0.18$ & $22.96 \pm 0.07$ & $23.28 \pm 0.24$ & $24.47 \pm 0.20$ \\
\hline Ciprofloxacin & $21.46 \pm 0.31$ & $22.64 \pm 0.54$ & $22.24 \pm 0.30$ & $23.82 \pm 0.47$ \\
\hline $\mathrm{NC}$ & - & - & - & - \\
\hline \multicolumn{5}{|c|}{ Minimum inhibitory concentration $\left(\mu \mathrm{g} \mathrm{mL}^{-1}\right)$} \\
\hline Composite material & 6.25 & 3.125 & 6.25 & 12.5 \\
\hline Ciprofloxacin & 6.25 & 3.125 & 6.25 & 12.5 \\
\hline
\end{tabular}

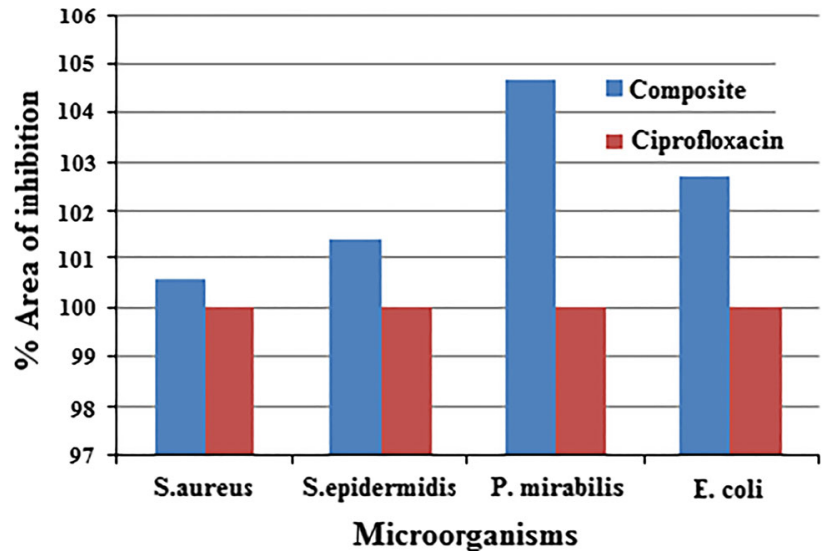

Fig. 6 Representing the comparative percent area of inhibition $\mu g^{-1}$ of the composite material and Ciprofloxacin in case of gram-positive and gram-negative bacteria

capability of the material in the separation of $\mathrm{Pb}^{2+}$ ion from synthetic mixture and real samples (industrial waste waters) was also explored. Table 1 and Table S3 show the successful separation of $\mathrm{Pb}^{2+}$ and $\mathrm{Hg}^{2+}$ ion from the synthetic mixture with $92-98 \%$ recovery. Identification of metal $\left(\mathrm{Ni}^{2+}, \mathrm{Pb}^{2+}\right.$, and $\left.\mathrm{Fe}^{3+}\right)$ was carried out by collecting waste water samples from various industrial sites in Aligarh, UP, India. The amount of $\mathrm{Ni}^{2+}, \mathrm{Pb}^{2+}$, and $\mathrm{Fe}^{3+}$ ions in the real samples was determined by using flame atomic absorption spectrophotometer and was found to be $(2.2,8.1$, and $\left.3.7 \mu \mathrm{g} \mathrm{L}^{-1}\right),\left(3.1,9.8\right.$, and $\left.2.2 \mu \mathrm{g} \mathrm{L}^{-1}\right),(9.7,9.8$, and $2.2 \mu \mathrm{g} \mathrm{L}^{-1}$ ), respectively (Table 2).

The results were validated by applying the standard addition method (spiking the water samples with a known amount $(10 \mu \mathrm{g})$ of individual metal ions). Results obtained by the direct method (applying the recommended procedure without spiking) are in close agreement with that found by the S.A. (standard addition after spiking), as it is evident from Table 2 that these close agreement of results indicate that present method for metal analysis in water samples is more authentic without any significant interference. The detection limit evaluated as three times the standard deviation(s) of the blank signal along with the mean blank signals (absorbance) for 15 replicate measurements was found to be 0.97(0.0027), 0.59(0.0099), and $0.32(0.0009) \mu \mathrm{g} \mathrm{L}^{-1}$ for $\mathrm{Pb}^{2+}, \mathrm{Ni}^{2+}$, and $\mathrm{Fe}^{3+}$, respectively.

\section{Biological activity}

In vitro antibacterial screening of nanocomposite material was evaluated against gram-positive ( $S$. aureus and $S$. epidermidis) and gram-negative ( $P$. mirabilis and $E$. coli) bacteria using disk diffusion method, and the results were compared with standard drug Ciprofloxacin. Results so obtained revealed that the composite material possesses better activity against both gram-positive and gram-negative bacteria. Antibacterial activity was calculated in terms of zone of inhibition (measured in $\mathrm{mm}$ ), and MIC was evaluated by the macro-dilution test using standard inoculum of $10^{5} \mathrm{CFU} \mathrm{mL} \mathrm{mL}^{-1}$. PSTM shows the lowest MIC values toward all the tested microorganisms (Table 3 ). The investigation of antibacterial screening data revealed that the material showed significant bacterial growth inhibition. Figure 6 represents the plot of the percent area of inhibition by composite material against all microorganisms and compared it with standard drug Ciprofloxacin.

\section{Conclusion}

Nanocomposite PSTM was synthesized via a simple chemical route with sorption capacity of $1.77 \mathrm{meq} \mathrm{g}^{-1}$. XRD analyses confirm the amorphous nature of the composite material. The capability of composite material was demonstrated in the separation of heavy metal ions from real and synthetic samples. Determination of $\mathrm{Pb}^{2+}$ ion in industrial wastewater by FAAS does not require any prior digestion. Electrical conductivity measurement results indicate that the material can be employed as a semiconductor in electrical and electronic devices. Investigation of 
antibacterial screening data revealed the significant bacterial growth inhibition. Thus, PSTM nanocomposite cation exchanger exhibits the characteristics of a promising ion exchanger, which can be explored for other applications.

Acknowledgments The authors are gratefully acknowledged the financial and technical support from Aligarh Muslim University and Universiti Sains Malaysia. One of the authors is grateful to the Universiti Sains Malaysia, for providing financial assistance through USM RU Grant (Grant Number 1001/PKIMIA/815099) for this work.

\section{References}

Akieh MN, Lahtinen M, Vaisanen A, Sillanp M (2008) Preparation and characterization of sodium iron titanate ion exchanger and its application in heavy metal removal from waste waters. J Hazard Mater 152:640-647

Bag S, Trikalitis PN, Chupas PJ, Armatas GS, Kanatzidis MG (2007) Porous semiconducting gels and aerogels from chalcogenide clusters. Science 317:490-493

Bushra R, Shahadat M, Nabi SA, Raeissi AS (2012) Development of nano-composite adsorbent for removal of heavy metals from industrial effluent and synthetic mixtures; its conducting behaviour. Desalination 289:1-11

Bushra R, Shahadat M, Ahmad A, Nabi SA et al (2014) Synthesis, characterization, antimicrobial activity and applications of polyanilineTi(IV)arsenophosphate adsorbent for the analysis of organic and inorganic pollutants. J Hazard Mater 264:481-489

Clarkson TW (1986) Effects-general principles underlying the toxic action of metals. In: Nordberg GF, Vouk V, Friberg L (eds) Handbook on the toxicology of metals, vol 1, 2nd edn. Elsevier, Amsterdam, pp 85-127

European Commission, Regulation (EC) (2006) No 1881/2006. JOL 364 pp 5-24

Figueroa E (2008) Are more restrictive food cadmium standards justifiable health safety measures or opportunistic barriers to trade? An answer from economics and public Health. Sci Total Environ 389:1-9

Gupta VK, Pathania D, Singh P (2014) Pectin-cerium (IV) tungstate nanocomposite and its adsorptional activity for removal of methylene blue dye. Int J Env Sci Tech. 11(7):2015-2024

Hafez MA, Kenway MM, Akl MA, Lshein RR (2001) Preconcentration and separation of total mercury in environmental samples using chemically modified chloromethylated polystyrene-PAN (ion-exchanger) and its determination by cold vapour atomic absorption spectrometry. Talanta 53:749-760

Hojati S, Landi A (2014) Kinetics and thermodynamics of zinc removal from a metal-plating wastewater by adsorption onto an Iranian sepiolite. Int J Env Sci Tech. doi: 10.1007/s 13762-0140672-2

Inamuddin Ismail YA (2010) Synthesis and characterization of electrically conducting poly-o-methoxyaniline $\operatorname{Zr}(1 \mathrm{~V})$ molybdate $\mathrm{Cd}(\mathrm{II})$ selective composite cation-exchanger. Desalination 250:523-529

Khan MA, Bushra R, Ahmad A, Nabi SA, Khan DA, Akhtar A (2014) Ion exchangers as adsorbents for removing metals from aquatic media. Arch Environ Contam Toxicol 66:259-269
Kurniawan TA, Chan GYS, Wai-Hung Lo, Babel S (2006) Physicochemical treatment techniques for wastewater laden with heavy metals. Chem Eng J 118:83-98

Lin YH (2014) Modeling chromium(VI) reduction by Escherichia coli 33456 using ceramic pearl as a supporting medium. Int $\mathrm{J}$ Env Sci Tech. 11(7):1887-1896

Mohamed Jaffer Sadiq M, Samson Nesaraj A (2014) Development of $\mathrm{NiO}-\mathrm{Co} 3 \mathrm{O} 4$ nano-ceramic composite materials as novel photocatalysts to degrade organic contaminants present in water. Int $\mathrm{J}$ Environ Res 8(4):1171-1184

Nabi SA, Naushad Mu, Bushra R (2009) Synthesis and characterization of a new organic-inorganic $\mathrm{Pb}^{2+}$ selective composite cation exchanger, acrylonitrile stannic(IV)tungstate and its analytical applications. Chem Eng J 152:80-87

Nabi SA, Shahadat M, Bushra R, Shalla AH, Ahmed F (2010) Development of composite ion-exchange adsorbent for pollutants removal from environmental wastes. Chem Eng J 165:405-412

Nabi SA, Shahadat M, Bushra R, Shalla AH (2011a) Heavy-metals separation from industrial effluent, natural water as well as from synthetic mixture using synthesized novel composite adsorbent. Chem Eng J 175:8-16

Nabi SA, Bushra R, Shahadat M (2011b) Removal of toxic metal ions by using composite cation-exchange material. J Appl Polym Sci 125(5):3439-3445

NTP (National Toxicology Program) (2002) 10th report on carcinogens. Department of Health and Human Services, Public Health Service, Washington, DC, U.S

Poyraz B, Taspinar F (2014) Analysis, assesment and principal component analysis of heavy metals in drinking waters of industrialized region of Turkey. Int J Environ Res 8(4):1261-1270

Saberi R, Nilchi A, Rasoli Garmarodi S, Zarghami R (2010) Adsorption characteristic of from aqueous solution using PANbased sodium titanosilicate composite. J Radioanal Nucl Chem 284:461-469

Shahadat M, Bushra R, Khan R, Rafatullah M, Teng TT (2014) A comparative study for the characterization of polyaniline based nanocomposites and membrane properties. RSC Adv 4:2068620692

Singh SR, Singh AP (2012) Treatment of water containg chromium (VI) using rice husk carbon as a new low cost adsorbent. Int $\mathrm{J}$ Environ Res 6(4):917-924

Su SJ, Kuramoto N (2000) Processable polyaniline-titanium dioxide nanocomposites: effect of titanium dioxide on the conductivity. Synth Met 2(114):147-153

Topp NE, Pepper KW (1949) Studies on new composite material polyaniline zirconium (IV) tungstophosphate Th(IV) selective cation exchanger. J Chem Soc 690:3299-3303

Vander Oost R, Beyer J, Verneykebm NPE (2003) Fish bioaccumulation and biomarkers in environmental risk assessment. Environ Toxicol Pharmacol 13:57-149

Vatutsina OM, Soldatov VS, Sokolova VI et al (2007) A new hybrid (polymer/inorganic) fibrous sorbent for arsenic removal from drinking water. Funct Polym 67:184-201

Xu JC, Liu WM, Li HL (2005) Titanium dioxide doped polyaniline. Mater Sci Eng C 4(25):444-447

Yang H, Rose NL (2003) Distribution of $\mathrm{Hg}$ in the lake sediments across the UK, Sci Total Environ 304(1-3):391-404 